\begin{tabular}{|l|l|l|}
\hline \multicolumn{2}{|c|}{ PublisherInfo } \\
\hline \hline PublisherName & $:$ & BioMed Central \\
\hline \hline PublisherLocation & $:$ & London \\
\hline \hline PublisherImprintName & $:$ & BioMed Central \\
\hline \hline
\end{tabular}

\title{
Mono-allelic expression in trypanosomes
}

\begin{tabular}{|l|l|l||}
\hline \multicolumn{2}{|c|}{ ArticleInfo } \\
\hline \hline ArticleID & $:$ & 4279 \\
\hline \hline ArticleDOI & $:$ & $10.1186 /$ gb-spotlight-20011217-02 \\
\hline \hline ArticleCitationID & $:$ & spotlight-20011217-02 \\
\hline \hline ArticleSequenceNumber & $:$ & 350 \\
\hline \hline ArticleCategory & $:$ & Research news \\
\hline \hline ArticleFirstPage & $:$ & 1 \\
\hline \hline ArticleLastPage & $:$ & 2 \\
\hline \hline & & RegistrationDate : 2001-12-17 \\
ArticleHistory & $:$ & OnlineDate $\quad$ 2001-12-17 \\
\hline \hline ArticleCopyright & $:$ & BioMed Central Ltd2001 \\
\hline \hline ArticleGrants & $:$ & \\
\hline \hline ArticleContext & $:$ & 130592211 \\
\hline \hline
\end{tabular}




\section{Jonathan B Weitzman}

Email: jonathanweitzman@hotmail.com

The parasite Trypanosoma brucei can exploit antigenic variation of its VSG coat proteins to avoid detection by the mammalian host. In the December 13 Nature, Navarro and Gull from the University of Manchester, UK, provide a mechanism for mono-allelic VSG expression (Nature 2001, 409:303). They investigated the role of RNA polymerase I (pol I) and nuclear compartmentalization in VSG expression. They used antibodies against $T$. brucei pol I to identify a 'pol I body' outside the nucleolus in the bloodstream-form of the parasite. This extranucleolar body was transcriptionally active and was absent in the procyclic-tsetse form. They used lac operator sequences to tag the active expression site locus to allow detection with a LacI-GFP fusion protein. Only active expression site loci were associated with the pol I extranucleolar body. Thus, localization to the extranucleolar body determines the VSG allele choice and defines a mechanism for pol I mono-allelic expression.

\section{References}

1. Mechanisms of antigenic variation in African trypanosomes.

2. Nature, [http://www.nature.com]

3. University of Manchester, [http://www.man.ac.uk] 